Such an inquiry also gives the teacher the chance to make insulting remarks about the person in question. The mention of Dupuytren will remind him to say that Dupuytren thought the contracture he described in coopers resulted from the pressure of the barrels on their hands. We now know that the contents of the barrels were likely to be more damaging than the casks. It is so much more effective to personalise one's insults, and if they can be directed to a defunct figure, likelihood of an action for slander is vastly diminished.

\section{Conclusions}

Purists may shun eponyms, but practical doctors appreciate their value. Those who use them need have no guilt complex, but rather a self righteous glow. For good, bad, and indifferent reasons eponyms will continue to be used and indeed should be. Clinicians, therefore, should be diligent in describing carefully new syndromes - their name may become attached to the symptom complex and thus they may be remembered by posterity.

1 Thompson P. Mister leprosy. Hodder and Stoughton, London: 1980. 2 Keat AC, Maini RG, Pegrum DG, Scott JT. The clinical features and HLA associations of reactive arthritis associated with non-gonococcal urethritis. Quart f Med 1979;48:323-42.

3 Still GF. On a form of chronic joint disease in children. Medico Chir Trans 1897;80:47-59.

4 Felty AR. Chronic arthritis in the adult, associated with splenomegaly and leucopenia: a report of five cases of an unusual clinical syndrome. Johns Hopkins Med Bull 1924;35:16.

5 Whipple GH. A hitherto undescribed disease characterised anatomically by deposits of fat and fatty acids in the intestinal and mesenteric lymphatic tissues. Bull fohns Hopkins Hosp 1907;18:382-9.

6 Reiter H. Über eine bisher unerkannte Spirochateninfection (Spirochaetosis arthritica). Dtsch Med Wchschr 1916;42:1535-8.

7 Paronen I. Reiter's disease: a study of 344 cases observed in Finland. Acta Med Scand 1948;131(suppl 212):1-123.

8 Mielants $\mathrm{H}$, Vey EM. Clinical and radiographic features of Reiter's syndrome in inflammatory bowel disease related to arthritis. Curr Opin Rheum 1990;2:570-6.

9 Sharp JT. Reiter's syndrome (reactive arthritis). In: Hollander JL, McCarthy DJ, eds. Arthritis and allied conditions. 8th ed. Philadelphia: Lea and Febiger, 1229-41.

10 Brodie BC. Pathological and surgical observations on diseases of the joints. London: Longman, 1818:54.

11 Scott JT, ed. Copeman's textbook of the rheumatic diseases. 6th ed. Edinburgh: Churchill Livingstone, 1986:787.

12 Bechterev VM. Steifigkeit der Wirbelsaule und ihre Verkrummung als besondere Erkrankungsform. Neurologisches Centralblatt 1893;12:426.

13 Strumpel A. Bermerkungen über die chronische ankylosirende entzudung der Wirbelsaule und der Hauftgelenke. Deutsche Zeitschrift fur Nervenhellkunde, 1897;11:338.

14 Marie P. Sur la spondylose rhizomelique. Reoue de Medicine 1898;18:285. 15 Wright V, Moll JMH. Seronegative polyarthritis. Amsterdam: North Holland Publishing, 1976.

16 Huskisson EC, Hart FD. Foint disease: all the arthropathies. Bristol: John Wright, 1973.

17 Crohn BB, Coinsburg G, Oppenheimer D. Regional ileitis - a pathological and clinical entity. JAMA 1932;99:1323-8.

\title{
Microbial flora on doctors' white coats
}

\author{
Derek Wong, K Nye, Pat Hollis
}

\begin{abstract}
Objective-To determine the level and type of microbial contamination present on the white coats of doctors in order to assess the risk of transmission of pathogenic micro-organisms by this route in a hospital setting.
\end{abstract}

Design-Cross sectional survey of the bacterial contamination of white coats in a general hospital.

Setting-East Birmingham Hospital, an urban general hospital with 800 beds.

Subjects -100 doctors of different grades and specialties.

Results - The cuffs and pockets of the coats were the most highly contaminated areas. The level of bacterial contamination did not vary with the length of time a coat had been in use, but it increased with the degree of usage by the individual doctor. Staphylococcus aureus was isolated from a quarter of the coats examined, more commonly from those belonging to doctors in surgical specialties than medical specialties. Pathogenic Gram negative bacilli and other pathogenic bacteria were not isolated.

Conclusions - White coats are a potential source of cross infection, especially in surgical areas. Scrupulous hand washing should be observed before and after attending patients and it may be advisable to remove the white coat and put on a plastic apron before examining wounds. There is little microbiological reason for recommending a more frequent change of white coat than once a week, nor for excluding the wearing of white coats in non-clinical areas.

\section{Introduction}

Wearing a white coat is an accepted part of medical practice. The actual use of white coats and how often they are changed varies greatly among individual doctors and their specialties. There has always been some concern that white coats, like nurses' uniforms : and other hospital garments, may actually play a part in transmitting pathogenic bacteria in a hospital setting. ${ }^{1-5}$ There has also been controversy over whether doctors should be barred from wearing white coats in areas such as staff canteens, tea rooms, and libraries. In this study we examined the white coats $\overrightarrow{\vec{O}}$ of doctors from East Birmingham Hospital for the presence of bacteria and in particular for potentially pathogenic bacteria.

\section{Methods}

One hundred doctors of different grades and specialties from East Birmingham Hospital participated in the study. The time that their white coat had been in use, how frequently they usually changed their coats, and the actual use of their coats were determined by direct questioning. The usage of a white coat was defined $\tilde{N}$ roughly as the percentage of time the coat was worn $D$ while the doctor was on duty. In addition, the cleanliness of the coat in appearance was subjectively $N$ assessed by a single observer. Of the 100 doctors, $45 \mathrm{~N}$ were house officers or senior house officers, 26 were $O$ registrars or senior registrars, and 29 were from consultant or other grades. A total of 51 worked in medical specialties, 38 in surgical specialties, and 11 in $\stackrel{?}{?}$ other specialties such as accident and emergency. Ten clean unused white coats were taken from the hospital $\bar{O}$ laundry as controls.

Impressions were taken from three different areas of $\underset{\mathbb{D}}{\mathbb{D}}$ the white coat using $25 \mathrm{~cm}^{2}$ contact plates containing $5 \%$ horse blood agar. The sites sampled were the cuff and the lower front pocket of the coat, where microbial 8 contamination was thought to be greatest as these are the most heavily used areas on a white coat. ${ }^{1-4} \mathrm{~A}$ further $\overline{0}$ sample was taken from the back of the coat at the level ? of the lower part of the scapula to assess background contamination. After 18 hours' incubation in air at $37^{\circ} \mathrm{C}$ the plates were examined for the total microbial 
count and the presence of possible pathogens, in particular Staphylococcus aureus and Gram negative bacilli. Suspect colonies were identified and antimicrobial sensitivities determined by standard laboratory methods. Nose swabs were taken from subjects if $S$ aureus had been isolated from their white coat. Any strains of $S$ aureus thus isolated were compared with the strain(s) isolated from their coat by comparing the antibiograms and phage types.

The total microbial counts were found to be consistent with a log normal distribution; they were transformed logarithmically and geometric means (referred to as means or averages in the rest of the text) compared by analysis of variance tests. The proportions of coats contaminated by $S$ aureus were compared by $\chi^{2}$ tests.

\section{Results}

Of the 100 doctors who took part in this study, 40 changed their white coats weekly, 31 fortnightly, 18 every two to four weeks, six every four to eight weeks, and five at intervals greater than eight weeks. Table I shows the overall results. The average count per $25 \mathrm{~cm}^{2}$ plate was 23.8 colony forming units. The cuff and the pocket had a significantly higher level of contamination than the back $(p<0 \cdot 05)$. Most of the organisms seen were skin commensals such as coagulase negative staphylococci and diphtheroid species. A total of 42 isolates of $S$ aureus were found on the white coats of 29 individuals and were more likely to be isolated from the cuff and pocket than the back $(\mathrm{p}<0.05)$. Gram negative bacilli were frequently seen but all those identified were environmental micro-organisms which are rarely associated with clinical disease. No other pathogenic bacteria were detected. The unused control coats turned out to be remarkably clean in all areas, with an average count of 1.7 colony forming units per

TABLE I - Bacterial contamination of white coats of 100 doctors

\begin{tabular}{lrrrr}
\hline & \multicolumn{5}{c}{ Location on coat } \\
\cline { 2 - 5 } $\begin{array}{l}\text { No of colony forming units } \\
\text { per } 25 \mathrm{~cm}^{2} \text { contact plate }\end{array}$ & Cuff & Pocket & Back & Total \\
\hline $\begin{array}{l}\text { Total microbes: } \\
0-19\end{array}$ & 32 & 38 & 53 & 123 \\
$20-49$ & 34 & 36 & 29 & 99 \\
$50-99$ & 20 & 16 & 12 & 48 \\
$100-199$ & 10 & 6 & 4 & 20 \\
$\geqslant-200$ & 4 & 4 & 2 & 10 \\
\hline Geometric mean & $30 \cdot 5$ & $24 \cdot 0$ & $18 \cdot 4$ & $23 \cdot 8$ \\
\hline Staphylococcus aureus: & & & & \\
$\quad 1$ & 8 & 4 & 1 & 13 \\
$2-5$ & 11 & 10 & 6 & 27 \\
$>5$ & 0 & 2 & 0 & 2 \\
\hline Total & 19 & 16 & 7 & 42 \\
\hline
\end{tabular}

$25 \mathrm{~cm}^{2}$ plate. No $S$ aureus was isolated from the control coats.

There were no statistically significant differences in the overall level of bacterial contamination in terms of the different grades of medical staff, the different specialties, the appearance of the white coat, ornotably-the time that the coat had been in use. However, coats that were more frequently used had significantly greater bacterial contamination at the cuff and back $(p<0.01)$ than those which were less frequently used (table II).

There were no significant differences in the likelihood of isolating $S$ aureus in terms of the different grades of medical staff, the appearance of the coat, the time in use of the coat or the actual usage of the coat (table II). $S$ aureus was significantly less likely to be isolated from the white coat of a doctor in a medical specialty than from a doctor in a surgical or other specialty (table II) $(p<0 \cdot 05)$. Specialties that had a high isolation rate for $S$ aureus included general surgery (nine out of 16 coats), orthopaedic surgery (four out of seven), and accident and emergency (four out of six).

$S$ aureus was isolated from the noses of 12 out of 25 $(48 \%)$ individuals whose white coats yielded $S$ aureus. Of the 32 strains of $S$ aureus that were isolated from the coats of these 25 individuals, only 11 strains had the same phage type as those found in the subject's nose $(35 \%)$. In one notable instance three different strains of $S$ aureus were isolated from the cuff, pocket, and the back of the coat; only the strain present on the cuff was similar to that present in the individual. Most of the strains isolated were resistant to penicillin only, and all strains were sensitive to methicillin. The phage types of the $S$ aureus isolated from the coats were compared with the phage types of $S$ aureus isolated from patients in the hospital during the period of the study, but no evidence of cross infection was found.

\section{Discussion}

In this study, contact plates were exclusively used for sampling. Although this method is less efficient than some others as only the surface is sampled,,$^{5-7}$ it is the only appropriate method in this instance as other methods involved mutilation of the garment. The method is probably more relevant when considering the risks of cross infection.

Microbial counts did not vary with the time in use of the white coat. A steady state of maximal microbial contamination was attained within the first week of use and did not change significantly thereafter. Similar results have been reported from other studies involving gowns, aprons, and nurses' uniforms, in which the steady state was attained within a day of use. ${ }^{46}$ This "plateau effect" also occurs with walls, floors, and curtains ${ }^{8}$ However, the level of contamination

TABLE II-Mean total bacterial counts and number of coats contaminated by Staphylococcus aureus related to time in use, level of usage, and specialty

\begin{tabular}{|c|c|c|c|c|c|c|c|c|c|}
\hline & \multirow[b]{3}{*}{$\begin{array}{l}\text { No of } \\
\text { coats }\end{array}$} & \multicolumn{8}{|c|}{ Location on coat } \\
\hline & & \multicolumn{2}{|c|}{ Cuff } & \multicolumn{2}{|c|}{ Pocket } & \multicolumn{2}{|c|}{ Back } & \multicolumn{2}{|c|}{ Overall total } \\
\hline & & $\begin{array}{c}\text { Mean total } \\
\text { bacterial } \\
\text { count }\end{array}$ & $\begin{array}{l}\text { No }(\%) \text { of coats } \\
\text { contaminated } \\
\text { by } S \text { aureus }\end{array}$ & $\begin{array}{c}\text { Mean total } \\
\text { bacterial } \\
\text { count }\end{array}$ & $\begin{array}{l}\text { No }(\%) \text { of coats } \\
\text { contaminated } \\
\text { by } S \text { aureus }\end{array}$ & $\begin{array}{c}\text { Mean total } \\
\text { bacterial } \\
\text { count }\end{array}$ & $\begin{array}{l}\text { No }(\%) \text { of coats } \\
\text { contaminated } \\
\text { by } S \text { aureus }\end{array}$ & $\begin{array}{c}\text { Mean total } \\
\text { bacterial } \\
\text { count }\end{array}$ & $\begin{array}{c}\text { No }(\%) \text { of coats } \\
\text { contaminated } \\
\text { by } S \text { aureus }\end{array}$ \\
\hline \multicolumn{10}{|c|}{ Time in use (weeks): } \\
\hline$<1$ & 55 & $30 \cdot 8$ & $9(17)$ & $25 \cdot 7$ & $8(15)$ & $19 \cdot 8$ & $4(7)$ & $25 \cdot 0$ & $17(31)$ \\
\hline $1-2$ & 26 & $41 \cdot 5$ & $7(27)$ & $29 \cdot 3$ & $7(27)$ & $22 \cdot 0$ & $3(12)$ & $30 \cdot 1$ & $8(31)$ \\
\hline $2-4$ & 9 & $23 \cdot 3$ & $1(11)$ & $15 \cdot 6$ & & $15 \cdot 1$ & & $17 \cdot 4$ & $1(11)$ \\
\hline$>4$ & 10 & $16 \cdot 3$ & $2(20)$ & $13 \cdot 8$ & $1(10)$ & $9 \cdot 3$ & & $12 \cdot 8$ & $3(30)$ \\
\hline \multicolumn{10}{|c|}{ Usage of coat: } \\
\hline$>75 \%$ & 55 & $40 \cdot 3$ & $9(17)$ & $27 \cdot 2$ & $6(11)$ & $23 \cdot 5$ & $2(4)$ & $29 \cdot 6$ & $11(20)$ \\
\hline $50-75 \%$ & 29 & $31 \cdot 8$ & $6(21)$ & $25 \cdot 6$ & $6(21)$ & $17 \cdot 1$ & $4(14)$ & $24 \cdot 0$ & $11(38)$ \\
\hline$<50 \%$ & 16 & $10 \cdot 5$ & $4(25)$ & $13 \cdot 7$ & $4(25)$ & $8 \cdot 8$ & $1(6)$ & $10 \cdot 8$ & $7(44)$ \\
\hline \multicolumn{10}{|l|}{ Specialty: } \\
\hline Medical & 51 & $36 \cdot 0$ & $6(12)$ & $24 \cdot 0$ & $5(10)$ & $22 \cdot 1$ & $1(2)$ & $26 \cdot 9$ & $7(14)$ \\
\hline Surgical & 38 & $27 \cdot 2$ & $9(24)$ & $24 \cdot 0$ & $10(26)$ & $17 \cdot 5$ & $4(11)$ & $22 \cdot 6$ & $17(45)$ \\
\hline Other & 11 & $20 \cdot 3$ & $4(36)$ & $23 \cdot 0$ & $1(9)$ & $9 \cdot 2$ & $2(18)$ & $16 \cdot 3$ & $5(46)$ \\
\hline
\end{tabular}


increased with the level of use of the coat, and coats that are used less frequently may require correspondingly longer to attain the steady state of microbial contamination. The white coats that were judged to be dirty did not differ in the level or type of microbial contamination from the clean white coats, which suggests that appearance does not necessarily indicate the degree of microbial colonisation.

The isolation of $S$ aureus from a white coat is related to personal carriage, as $48 \%$ of the doctors from whose coats $S$ aureus was isolated carried the organism in their noses. However, $S$ aureus was more likely to be isolated from the coats of doctors in some specialties, especially surgical specialties. Therefore, potential does exist for cross infection in surgical areas, particularly during examination of wounds postoperatively, although there was no evidence of such cross infection from this study.

Pathogenic Gram negative bacteria were not isolated in this study and were reported infrequently in other studies. ${ }^{49}$ This may be due to the fact that many of these organisms need a warm moist environment for survival, which is not present on the white coats. It was not within the scope of this study to assess viral contamination of the coats, although it is known that several common viruses, such as enteroviruses and small round structured viruses, survive well within the environment and may be transmitted by fomites.

Some conclusions can be drawn from this study. There is little microbiological reason for recommending a more frequent change of white coat than once a week. However, there is potential for cross infection with $S$ aureus, particularly among the surgical specialties. During clinical examinations the cuffs of white coats come into frequent close contact with patients' clothing and skin, at which point bacteria may be both acquired from and transferred to the patient. White coats with close fitting cuffs might help to reduce this problem, although it may be better to remove the white coat and put on a plastic apron before examining wounds. Also, as contamination of the hands is highly likely to occur from organisms present on the cuff, 0 and vice versa, scrupulous hand washing should be observed before and after attending patients. Finally, this study contains minimal microbiological evidence? to support the exclusion of white coats from non-o clinical areas of the hospital such as libraries and dining rooms.

We thank Dr J Kavi and other colleagues at the Regionalo Public Health Laboratory at East Birmingham Hospital for their technical help and advice. We also thank the Staphylococcus Reference Unit at the Central Public Health Laboratory for carrying out the phage typing on the $S$ aureus isolates.

1 Lidwell OM, Towers AG, Ballard J. Transfer of microorganisms between nurses and patients in a clean air environment. $\mathcal{F}$ Appl Bacteriol 1974;37: 649-56.

2 Ransio U. Attempts to control clothes-borne infection in a burns unit. $2 \infty$ Clothing routines in clinical use and the epidemiology of cross-colonization

Journal of Hygiene 1979;82:369-84.
3 Speers R, Shooter RA, Gaya H, Patel N, Hewitt JH. Contamination of nurses' uniforms with Staphylococcus aureus. Lancet 1969;ii:233.

Bab JR, Davies JG Ayliffe GA. Contaminato of pros. nursesthing and $O$ Infect 1983;4:149-57.

Hambraeus A. Transfer of Staphylococcus aureus via nurses' uniforms. N foumal of Hygiene 1973;71:799-814.

6 Nystrom B. The contamination of gowns in an intensive care unit. $\mathcal{F}$ Hosp Infect $\square$ 1981;2:167-70.

7 Nicoles PS. Bacteria in laundered fabrics. Am f Public Health 1970;60:2175.

8 Ayliffe GAJ, Collins BJ, Lowbury EJC, Babb JR, Lilly HA. Ward floors and

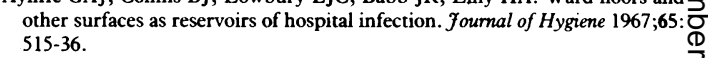

9 Robinton ED, Mood EW. A study of bacterial contaminants of cloth and paper towels. Am F Public Health 1968;58:1452.

\title{
Do pathologists have extrasensory perception?
}

\author{
A D Bull, S S Cross, D S James, P B Silcocks
}

Extrasensory perception (ESP) may be defined as the divination of knowledge without recourse to the appreciation of light, sound, temperature, or movement. This talent has been recognised in some of the earliest cultures and has been considered both a gift and a curse; a sign of virtue or of evil, of deity or of devilry. It has been attributed to witches, prophets, necromancers, soothsayers, and clairvoyants, and it has been used for religious, political, sociosexual, and sporting purposes. Almost without exception the possession of this ability has lent fame, fortune, and notoriety to its owner. The exception is the histopathologist, who nevertheless has long been held by all medical practitioners to be a master of this art.

In early medical practice the physician was able to divine the imbalance of the four humours-phlegm, blood, black bile, and yellow bile - and thereby ascertain the nature of a disease and its cure. With such a long history of divination as an integral part of medicine it is hardly surprising that when Giovanni Battista Morgagni began the medical renaissance by relating morbid anatomy to symptoms and signs in his patients, ${ }^{12}$ therefore removing the need for the divination of the humours, that the art was transferred to his descendants, the histopathologists, who were considered able to divine the symptoms and signs from the morbid anatomical findings alone.

The current vogue for clinical audit has not approached the assessment of this aspect of pathological practice. Indeed, it is not mentioned once in the government's white paper. We consider that thisomission should be made good and the clairvoyant ability of the histopathologist be properly tested.

\section{Method and results}

A total of 48 histological sections of basal cell carcinomas from two men and two women born under each of the 12 star signs, matched within five years of 0 age, was screened to exclude features that might give as clue to gender, such as Oil of Ulay and sycosis barbae. The slides were coded and circulated in random order to a mixed group of 10 pathologists for assessment of sex and star signs. The pathologists examined the ${ }^{\omega}$ sections under low power magnification only (up to $100 \times$ total magnification) to prevent the recognition of sex by Barr bodies.

To assess the correctness of observers' ratings a $x$ type of statistic was derived from the statistic described by Light for testing the agreement of observers with a standard. ${ }^{3} x$ Statistics were also used to measure the degree of interobserver agreement. ${ }^{4}$ In both cases a bootstrap method was used to estimate the confidence intervals. ${ }^{5}$ These intervals were calculated in two ways: firstly, for this particular group of pathologists (fixed observers) and, secondly, for pathotôे logists in general (random observers), based on the assumption that this particular group is a random sample from the pool of potential observers. $A x$ value of 1.0 indicates perfect agreement, zero indicates 